\title{
Identification of Learning Model Including Conservation Value in College As A Strength Of Students' Character
}

\author{
Isnarto $^{1}$, Nur Rahayu Utami ${ }^{2}$, Asep Purwo Yudi Utomo ${ }^{3}$ \\ ${ }^{1,2,3}$ Graduate School, Universitas Negeri Semarang, Indonesia \\ ${ }^{1}$ Corresponding email: isnarto.math@mail.unnes.ac.id
}

\begin{abstract}
Learning in college requires continuous innovation and development. One of the development which is needed is the development of learning model. One of the points inside is the implementation of conservation value which is used as a means of strengthening the character of students in universities. This study aims to describe the level of need for learning KKNI Curriculum and Conservation models at the State University of Semarang as a part of the development of learning models. The research methods used are Research and Development, with the preliminary study stage in the form of questionnaires (list of questions), a check listing, and an interview instrument. From this analysis, it is found that (1) some lecturers have implemented conservation values both consciously and unconsciously, (2) there are variations in implementing conservation values that can be sampled because of their uniqueness, (3) there are variations in the use of learning model and describing the model of learning conducted by lecturers. In addition to the general findings, there are special findings regarding inspirational, humanist, caring, innovative, creative, sportive, honesty, and fair conservative values reflected in more specific indicators. Examples of inspirational value indicators include (1) motivating, (2) being the first, (3) getting better.
\end{abstract}

Keywords: identification of learning model, college, conservation, student character

\section{Introduction}

Learning in Higher Education requires continuous innovation and development. One of the development which is needed is the development of learning model. Gunter et al (1990: 67) defines the instructional model as a step-by-step procedure that leads to specific learning outcomes. Joyce \& Weil (1980) define the learning model as a conceptual framework used as a guide in learning. Thus, the learning model is a conceptual framework that describes a systematic procedure in organizing learning experiences to achieve learning objectives. So the learning model tends to be prescriptive, which is relatively difficult to distinguish from the learning strategy. An instructional strategy is a method for delivering the instruction that is intended to help students achieve a learning objective (Burden \& Byrd 1999: 85).

The intention of current global development demands equality of ability and recognition of learning achievement in each university that has been synchronized internationally which is marked by the presence of KKNI. With the development of the KKNI, independently since 2015 it experienced a shift by providing standard measures of equalization of learning achievement. The curriculum based on KKNI provides equal achievement to the ability of university graduates who have been equalized to maintain the quality of each college graduate. On the basis of the conditions and demands as already stated, the College aligns its academic capacity support to the demands of achieving its international vision on the one hand and global dynamics on the other. (KKNI and Conservation Curricula 2015: 7-8).

For example, conservation is placed as a spirit that animates the whole motion and dynamics of Semarang State University. Conservation University is a university that in the implementation of Tri Dharma Perguruan Tinggi refers to the principles of conservation (protection, preservation and sustainable use) natural resources and cultural arts, and environmentally sound. The development of Unnes into a conservation-oriented university has a number of objectives: (1) supporting the government's efforts in implementing the biological resources and ecosystems management; (2) Making Unnes as a reference or reference of conservation-oriented universities in Central Java; (3) protecting, preserving, and utilizing natural resources sustainably in the environment of Unnes and its surroundings through educational, research and community service activities for the creation of an ecosystem balance; and (4) cultivating responsible mental and behavioral attitudes and the participation of all UNNES citizens in 
conservation of biodiversity and conservation of the environment and art and culture. (KKNI and Conservation Curriculum 2015: 11).

In order to instill the values of character and also to participate in the mental revolution, one of which is realized by conducting lectures. The lectures are a series of courses that are essentially intended as an effort to form students' character. The course needed is the one that seeks to equip students, not only from the cognitive aspect, but also the affective and psychomotor aspects. In other words, the graduates of Unnes can actually implement the four pillars of education, as proposed by The International Commission on Education for $21^{\text {st }}$ Century. The four pillars are learning to know, learning to do, learning to be, and learning to live together.

The ideal plan which is available in the curriculum needs to be translated by lecturers in Semester Learning Plan (RPS) and in every lecture activity held. So that later the main purpose of curriculum development can be achieved optimally.

The researcher, taking into account the above matters, argues that the lecturers need to have an accurate recipe of innovative and creative learning models. Hopefully, the indicators of learning achievement as outlined in the curriculum can be achieved optimally. The problem is, not all proficiency lecturers are able to translate the curriculum well. The implication is that lecturers teach without innovation, creation and adaptation with the new curriculum. Lecturers rely on what was usually done in teaching the class before, in the previous semesters.

This study aims to identify the model of learning in conservation-based universities by finding the level of need for the model of learning in conservation-based colleges as a student character enhancer as well as a model of learning in conservation-based universities as a character booster of students who have opportunities developed and implemented in learning.

Previous research discussed in this study is taken from various research results which has been done dealing with the model of learning, curriculum, and character. Thompson (2002) writes an article entitled "The Effects of Character Education on Student Behavior." Rahayuningsih's Research, Dewi Lisnoor, Tsabit A (2012) on "Improvement of Educational Materials for Character Living
Environment at Semarang State University". Masrukhi (2012) writes articles entitled "Building Conservation Value-Based Character." Yuniawan, Masrukhi, Sri Rejeki, Tsabit (2015) conducted a first-year research on "Ecolinguistic-Based Conservation Value-Based Discourse Models for Enrichment of Teaching Materials Environmental Education Course Life".

In addition to observing the theoretical rationale, objectives, and outcomes to be achieved, the learning model has five basic elements (Joyce \& Weil 1980), namely (1) syntax, i.e. operational learning steps, (2) social system, which is the atmosphere and norm (3) principles of reaction, that describes how teachers should view, treat, and respond to students, (4) support systems, any means, materials, tools or learning environments that support learning, and (5) instructional and nurturant effects - Learning results obtained directly by instructional effects and nurturant effects.

\section{Methods}

Data collection methods used are document-collecting methods and questionnaires (list of questions), a check listing, and interview instruments. Data was analyzed using quantitative and qualitative descriptive analysis techniques. The analysis of the data is part of the research approach used in this research: Research and Development (Borg and Gall 2003: 571), which is the preliminary study phase.

Preliminary phase of the study that will be done is the identification of the level of development needs of the conservation value learning model in the university as a reinforcement of student character. Primary data source in this research is respondent according to calculation on sampling technique. While the secondary data source is a source of literature and on-line or manual data tracking. Sources of literary data written in this study were obtained from supporting documents.

The validity of data in this research is taken using triangulation technique, that is technique of examination of data. (1) comparing observation data with the interview data; (2) comparing what people say in public with what they say personally; (3) comparing the situation and perspective of a person with the various opinions and views of people such as ordinary people, middle or high educated people, resident 
people, government people; (4) comparing interview data with the contents of a related document.

\section{Results and Discussion}

Requirement level of learning model in a conservation-based university as the reinforcement of student's character according to students and lecturers includes the things presented as follows. The number of students who become the sample is 200 and the number of lecturers who become the sample is 15 .

\section{Student's Knowledge of Conservation Implementation in Learning}

The students' knowledge of the conservation implementation in learning can be summarized as follows.

First, the implementation of conservation values is not evenly distributed among all students. This is reflected in the varied student responses. Most of them said that the implementation already exists though not deep and some are delivering that the implementation is enough. It is seen from the understanding of students who are imperfect. The imperfection is evident from the understanding of conservation values that are only understood by half.

Second, in each field of science there has already been a common answer in general, meaning that the understanding of the conservation value is not maximal. No student in a particular field of knowledge dominates the understanding of conservation value. Students tend to better understand the value of conservation that suits their field of knowledge.

Third, the basic concept of conservation value is not yet intact so that it can not give full understanding or implementation as well. This is a note to simplify the concept of conservation value and related indicators.

Fourth, the lecturers have applied the conservation vision in the learning which has two understandings, that is implementing the conservation vision as a whole and applying the conservation vision in part. This is reflected in the statements of students of social science courses, the exact sciences, the linguistic and arts sciences, and educational sciences which state that conservation value is delivered directly or indirectly by lecturers in learning.

The findings are in line with the study (Aisha A.R. 2014) which asserts that value retention can be developed through the knowledge stage; knowing, acting, and habits. The results of the character education implementation process can be achieved through the emotions and habits of the students, so that the implementation can achieve good character which is the moral knowledge, moral feeling, and moral behavior (moral action).

\section{The dominance of Implemented Conservation Values}

Based on the statement "UNNES menjabarkan spirit konservasi ke dalam 8 nilai yaitu inspiratif, humanis, peduli, inovatif, kreatif, sportif, jujur, dan adil." There is a tendency and value dominance to be implemented.

Among the social-science-subject students who are dominated by students from the Faculty of Social Sciences, there are some dominant and less dominant values that can be implemented in learning. Dominant values include caring, humanist, honest and fair value; while less dominant values are inspirational, creative, vivative, and sportive.

Among the exact-subject students who are dominated by students from the Faculty of Engineering and Faculty of Mathematics and Science, there are some dominant and less dominant values that can be implemented in learning. Dominant values include inspirational, creative, vivative, and sportive values; while less dominant values are caring, humanist, honest, and fair.

Among college students of language and arts classes who are dominated by students of the Faculty of Languages and Arts, there are some dominant and less dominant values that can be implemented in learning. Dominant values include humanist, caring, honest, inspirational and fair values; while less dominant values are creative, vivative, and sportive.

Among the students of education classes who are dominated by students from the Faculty of Education, there are some dominant and less dominant values that can be implemented in learning. Dominant values include inspirational, humanist, caring, honest and fair values; while less dominant values are creative, vivative, and sportive.

The dominance of the values that appear in the identification is not only happening in Indonesia. The same happens in Singapore, in research (Istiningsih 2016: 32) which states that there are seven distinct types of characters in 
Singapore: the emotionless, disciplined, respectful of one another, such as being hygiene, being endurance in work, respecting for others' work, both in service and communication. In addition, there are thirteen types of abilities that are assumed to be able to build character motivation. Thirteen kinds of these abilities in this study are considered as the pillars of education.

The dominance of conservation values is also in line with the concept (Wibowo 2018) which describes the value of conservation in indicators dealing with conservation values. Indicators that are presented and developed are in accordance with the context of its development.

The indicator of inspirational values is (1) giving hope, (2) giving motivation, (3) always being first, (4) wanting to be remembered, (5) positive thinking towards something, (6) increasing curiosity of others, 7) being a helper, (8) willing to sacrifice time, thought, energy, and property, (9) always renewing themselves, and (10) loving to read.

The indicator of the value of the caring character is (1) sympathy, (2) empathy, (3) generousity, (4) altruis, (5) giving, (6) having initiative, (7) willing to sacrifice, (8) do not selfish, (9) prioritizing usability for others, (10) sincere.

The indicators of the value of innovative characters are (1) a lot of sense, (2) many ideas, (3) tough, (4) ambitious, (5) hardworker, (6) socialable, (7) responsive and smart, (8) logic, careful, and detail, (9) always innovative, and (10) always contributive.

The indicator of the value of the creative character is (1) has a lot of sense, (2) has many ideas, (3) is tough, (4) is sure what is proposed good and right, (5) thinks from all directions, (6) considers process, (7) is able to think fast and precisely, (8) respects the views of others, (9) always takes the initiative, and (10) gives the best.

The indicator of the value of the sportive character is (1) acknowledging that the other person is right, (2) upholding the truth, (3) loving kindness, (4) being confident with what is thought, spoken and done seen by Allah SWT, (5) sure that everything will be paid off, (6) never wants to disturb others, (7) does not always take advantage, (8) can accept defeat, (9) does not like to cheat, and (10) will admit that his actions are wrong.
Indicators of honest character values are (1) saying as it-is, (2) sportive, (3) no facts are hidden, (4) being sure what is thought, spoken and done seen by God, (5) being confident that what is done will get paid off, (6) intolerance of negativity, (7) non-duplicity, (8) caring about the fate or future of others, (9) feeling embarrassed while doing bad deeds, and (10) not soul-pleasing.

The indicators of fair character values are (1) non-discriminatory, (2) impartial, (3) not self-prioritizing, (4) deciding on the basis of provisions, (5) prioritizing obligations, (6) maintaining a balance between rights and obligations, 7) being consistent, (8) accepting whatever is decided, (9) accepting the consequences of what has been done, and (10) considering something before it is decided.

\section{Learning Model Most Frequently Used by Lecturers in Learning}

Lecturers have a tendency in learning. These tendencies include: (1) using the same method, technique, or model of learning in the taught course, (2) using the same learning pattern from semester to semester by habit, (3) using different learning models if the case is in process learning.

The tendency is supported by the use of the model used consistently by the lecturers, among others: (1) the scientific learning model, (2) the inquiry learning model, (3) coorperative learning, (4) problem-based learning, (5) paedagogis genre, (6) project-based learning, (7) discovery learning, (8) One-way Lecturing, (9) Mind-mapping, (10) independent presentation.

Of the ten learning models that are often used, there are still a one-way lecturing and independent presentations. It illustrates that there are still findings that need to be followed up as part of the development of learning in college.

\section{Conclusion}

On the basis of the results of the research presented, it can be summed up things as follows. The level of need for the learning model in conservation-based universities as a character-booster of students is obtained on the basis of inputs of students and lecturers. Aspects developed include conservation value aspect, implementation of conservation value, learning model, and application of learning model. From the results of the analysis, it is found that (1) some lecturers have implemented conservation 
values, (2) there are variations of implementation of conservation values that can be used as examples; (3) there are variations in the use of learning models and describing interesting learning models; (4) it is necessary to develop learning model which reinforces the value of conservation.

The results of this study can be used in lectures for lecturers and students in implementing the conservation values. The results of identification can be used as a reflection to improve the quality of learning whether to develop cognitive, affective, and psychomotor abilities.

\section{References}

Aisyah. A. R. (2014). The Implementation Of Character Education Through ContextualTeaching And Learning At Personality Development Unit In The Sriwijaya University Palembang. International Journal of Education and Research, Vol. 2 No. 10 October 2014.

Borg, W. R. \& Gall, M. D. (2003). Educational Research: an Introduction (7th ed.). New York: Longman, Inc.

Burden, P. R., \& Byrd, D. M. (1996). Method for Effective Teaching, Second Edition. Boston: Allyn and Bacon.

Gunter, M. A., Estes, T. H., \& Schwab, J. H. (1990). Instruction: A Models Approach. Boston: Allyn and Bacon.

Istiningsih. (2016). Character Education of the Most Developed Countries in ASEAN.
Journal of Education and e-Learning Research, 3(1): 32-37.

Joyce, B., \& Weil, M. (1980). Model of Teaching. New Jersey: Prentice-Hall, Inc.

Masrukhi. (2012). Membangun Karakter Berbasis Nilai Konservasi. Indonesian Journal of Conservation Vol. 1 No. 1 Juni 2012 [ISSN: 2252-9195] Hlm. 2029

Rahayuningsih; Dewi Liesnoor Setyowati, dan Tsabit Azinar. (2012). Pengembagan Bahan Ajar Pendidikan Lingkungan Hidup Berkarakter di Universitas Negeri Semarang.

Thompson, William G. (2002). The Efects of Character Education on Student Behavior. East Tennessee State University Digital Commons @ East Tennessee State University Electronic Teses and Dissertations 12-2002

Tim Pengembang Kurikulum Unnes. (2015). Kurikulum Unnes 2015 (KKNI dan Konservasi).

Yuniawan, Tommi; Masrukhi; Sri Rejeki, dan Tsabit Azinar. (2015). Model Wacana Berwawasan Nilai-Nilai Konservasi Berbasis Ekolinguistik Sebagai Pengayaan Materi. Penelitian. Universitas Negeri Semarang.

Wibowo, Mungin Eddy. (2017). Tiga Pilar Konservasi Penopang Rumah Ilmu Pengembang Peradaban Unggul. Semarang: Unnes Press. 